\title{
Social Influence and Individual Financial Behavior for Digital Banking: A Causal Study
}

\author{
Tarika Singh Sikarwar \\ Professor, Management Department \\ Prestige Institute of Management Gwalior, India \\ E-mail: tarika.singh@prestigegwl.org or singh.tarika@gmail.com
}

Received: October 21, 2019 Accepted: November 18, 2019 Published: November 25, 2019

doi:10.5296/ijafr.v9i4.15905

URL: https://doi.org/10.5296/ijafr.v9i4.15905

\begin{abstract}
Digital banking is a buzz word these days. There are many factors responsible for the adoption and usage of digital banking. The study is being done to known the factors of social influence, financial behaviour. The study had been done to check the causal association between these study variables in context of digital banking. The results showed presence of association between "social influence" and individual "financial behaviour" for digital banking where in "values" and belief are having mediating role. The "Values" and belief of the individual are influenced by the society in which individual lives and in turn they affect the "financial behaviour" of an individual. The outcomes of the study will aid the to know the role of "Social Influence" via "values" and belief on individual financial behavior specifically related to digital banking platforms or transactions.
\end{abstract}

Keywords: Social influence, Financial behaviour, Digital banking, Values and beliefs

\section{Introduction}

Psychology and Behavioral economics are related fields (Kahneman, 2003). Since ages, Behavioral economics is of the view that human behaviour is guided by not only by rationality but by factors like emotions, "Social Influence", "Values", culture etc. (Triplett, 1898). "Financial behaviour" shown for any type of banking aspect and the decisions taken are product of influence of many social factors. The kind of behaviour shown by an individual are shaped by their primary influence groups. "social influence" hence, plays a very important role in individual financial behavior. "Social Influence" refers to peer influence and parent socialization. "Social Influence" includes the use of social power by a person or group for changing the attitude or behavior of other persons in the desired course and for specific thing. 
Individual investors happily follow larger groups specially when financial decisions are taken into consideration. Besides parenting factors, peer influence also predicts individual's financial behavior. The effect is much when behaviour related to digital banking platforms is formed. Individuals cooperate with others in a specific social setting which straight or indirectly influence their financial behavior. Social environment culture, sub culture and social class, powerfully influence the "Values" norms and behaviors, including the financial behavior of individual. The "Values" surrounding different aspects of lives through socialization affects the behaviour. Therefore, the main aim of the research work is to find the connection between "Social Influence" and individual financial behavior through "Values" and "Beliefs" for digital banking.

\section{Conceptual Framework}

"Social Influence": According to H.C. Kelman (1958) "Social Influence" is intentional or unintentional change that one person causes in the behaviour of another person. There can be many forms of "Social Influence" which can be seen like changes in levels of "socialization", "peer pressure", "obedience", "leadership", "persuasion", "sales" and marketing. Broadly the "Social Influence" can be categorized in form of "Compliance", "Identification" "Internalization" and "Values".

"Values": There are many definitions of "values" given as per the requirements and field of study. Like Smith and Schwartz (1998) have described the core meaning of "values" as "Values" serve as standards to guide the selection or evaluation of behavior, people, and events". Grube et al. (1994) had discussed that "Values" play a central role as they are the depiction of individual requirements and wants, as well as of what society demands from others.

"Beliefs": Beliefs can be defined in terms of "state of mind" wherein one person places trust or confidence in others (Primmer. 2018).

"Financial behaviour": Behaviour can be defined as the way in which someone conducts oneself or behaves. "Financial behaviour" relates to financial management or money management.

Behaviour towards Digital Banking: In the Digital Banking behaviour, the theoretical background can be understood from acceptance of information technology (IT). The behaviour towards, IT have been taken from social psychology like theory of planned behaviour talks about behavioral intentions for the use of technology (Ajzen, 1991). The innovational Diffusion Theory given by Rogers tells that innovation adopted by individual remains uncertain. The individual first gathers information about technology and further on the basis of "Beliefs" they can accept or reject a technology. In line with this, there is theory of Reasoned Actions which focuses on the part that it is the belief within individual which lead to acceptance or rejection behaviour in individual for technology. As per this theory usage intention are affected by attitude and norms.

Theory of planned behaviour is yet another model explaining the behaviour towards adoption of technology (Ajzen and Fishbein, 2009) the model explains behavioral intentions through 
perceived behavioral control. "Technology acceptance model" is also a refined model prediction individual behaviour towards adoption of technology through Attitudes. As per this model, Attitude predicts intentions which in turn is determined by "perceived usefulness" and "perceived ease of use". The adoption of the Theory of Planned Behavior in the decomposed "theory of planned behavior" is a combination of "theory of planned behavior" and innovation diffusion theory. As per this theory, "attitude, subjective norm and perceived behaviour" together determine intention to use the technology.

This research paper is organized as follows in: Section 1 overview and conceptual framework were there and in Section II examination of the literature, the data and presents the research methodology and in Section III discussion and the results were there while in Section IV Conclusion

\section{Review of Literature}

Association between social behaviour and economics is studied in a branch know as social economics. This branch throws some light on how norms prevalent in the society, sentiments of people, "beliefs" of individuals and groups, influence the financial decision making by any individual. Historical events, current events and changes like political, social and such other events lead to changes in the in socio-economic platform and are reflected in behaviour of individual. Hence, "social influence" has vital role in the "financial behaviour" of individual. This is applied in case of Digital Banking as well. Banking these days has undergone radical transition from traditional platform to digital platforms. "Beliefs", "values" and attitudes of an individuals are meaningfully affected by socioeconomic status too (APA). Therefore, "beliefs", "values" and attitudes will have impact of individual behaviour. "Beliefs" and "values" also influence the individual behaviour for digital banking. Though, here it can be noted that traditional theories consider investors as rational decision maker but socio economic theories consider traditional theories as contrary to their view. Looking into this, the following section has tried to explore the literature available on these associations.

\subsection{Association Between "Beliefs" and Individual Financial Behavior}

Banking Industry is these have most of the transactions done online. This industry is getting benefitted with e-services with lower cost. But there is still problem in the acceptance behaviour shown by individuals. Beliefs is the most important factor affecting the individual's behaviour for digital banking (Alsajja and Dennis, 2010 and Hsu, Lu and Hsu, 2007)). Odek, 2013 in his work has quoted that individuals express real "financial behaviour" which is guided by their previous experiences, "beliefs" and prior knowledge. The usage of digital banking platform being one of them. This leads to irrational behaviour sometimes even when they are literate in financial terms. This indicates that one can achieve his/her financial goals, show acceptance and rejection for a technology even when they are not much aware and rational (Gigerenzer \& Gaissmaier, 2011). Surety about the safest of their financial details and up to date financial services also lead to positive or negative behaviour towards digital banking (Solomon, Shamsuddin and Wahab, 2013). 
"Beliefs" are also shaped by past income levels, expenditure, savings done by individual (HINGA, 2012). Financial literacy is also an another contributing variable towards financial actions related of technology Demirhan et al. (2019); Postmus (2011). Ajzen (2005) further explained that "Beliefs" are shaped through intentions. Mustikasari (2007) further added that "Beliefs" are linked with the consciousness of one's behavior. Money "Beliefs" and financial practices were studied and four different money "Beliefs" patterns were identified which incorporate money evading, money reverence, and money position and money watchfulness (Brad klonzet al, 2011).

In the early 1977, Bandura proposed that individuals carry forwards the money skills cultured in childhood ((Furnham, 1996; Kirkcaldy \& Furnham, 1993, Klontz and Klontz (2009). Furnham (1984) for the work he did for his "Money Belief and Behaviour Scale", came with the conclusion of a belief that hard work is rewarding. In line with the Social Learning theory given by Bandura (1977), (Klontz, Britt, Mentzer, \& Klontz, 2011) said in their work that that "Beliefs" of money and money skills of an individuals are cultured in juvenile and carried to adulthood either consciously or un-consciously (Furnham, 1996; Kirkcaldy \& Furnham, 1993) and applies to acceptance of technology enabled digital banking operations too.

\subsection{Association Between "Values” and Individual Financial Behavior}

"Values" are the standards or principles used for evaluating and determining behaviors, characteristics, or goals regarded as desirable". Individual uses "values" as plans for discriminating urgencies, for creation of trade-offs, for making likings, and for creating-or not creating-decisions. Clyde Kluckhohn (1951) defined "Values" as "a conception, explicit or implicit, distinctive of an individual or characteristic of a group, of the desirable, which influences the selection from available modes, means, and ends of action". "Values" are guided by individuals psychological and spiritual desires and the load of people. "Values" erudite from the experiences as well as taught in the schools, family and organizations.

"Values" are responsible for creating a "mental financial values system" and have an effect on the financial life of an individual as they drive the financial decisions of an individual be it usage of digital platforms or traditional platforms. The "Values" are embedded even the particular necessities for impartiality and fairness in financial dealings. "Material "Values" which can be considered as the attitudes towards consumption, further explains financial behavior.

Cokely and Kelley (2009) researched that better decisions involving risk, specifically lotteries, gambling, online money transfers are results of quantitative reasoning. They established that "People higher in working memory span, cognitive reflectiveness, and those with greater skill in comprehending and transforming probabilities often made choices consistent with expected value". Lusardi and Mitchell (2007) had given proof that measureable financial literacy is vital in understanding digital banking platforms and using the same for superannuation planning. They measured financial literacy" as a blend of quantitative literacy and institutional knowledge. 
3.3 Association Between "Social Influence" and "Financial Behavior"

"Social Influence" can be defined as "the use of social power by a person or group to change the attitude or behaviour of other persons or groups in a particular direction" (Franzoi, 2006 in Jamal et al. (2015)). Parents play and important role in the "financial socialization" (Clude et. al., 2006; Sam et. al, 2012), of their children and hence parents play a crucial role in influencing the development of "financial behaviour" of the children. Parents are the role models of their children in "financial behaviour" and have serious impact on the orientation of future financial orientation of children. The role of parents in shaping financial attitudes and behaviour is even more crucial than that of school and society (Shim et. al. (2010), Norvitilis and Maclean (2010), Borden, Lee, Serido, and Collins (2008), Robb et al. (2012), and Murugiah (2016), Alekam, Salleh and Mokhtar (2018). Capuano and Ramsay (2011) in their work have further identified the community, psychological and cognitive causes of suboptimal and irrational consumer behaviour. They had studied about impact of "Social Influences on "financial behaviour" and found a positive association between these. Jamal et al. (2015) had indicated the role of family involvement in savings behavior, financial literacy, technology acceptance and peer influence for children. Further, adding to it they also emphasized role of financial literacy on the formation of financial attitude. There is also an influence of fathers on the financial behavious of children because of their concerns towards children (McHale et al (2003).

\subsection{Association Between "Social Influence" and "Values"}

Few of the basics of culture are "Values", language, myth, customs, rites, law and artefacts" or yields approved down from ages to ages (Lamb, Hair, and Daniel, 2011). These "Values" tend to influence consumer behavior with reference to online transactions and group of range standards used by individual person (Tahmid Nayeem, 2012). Yung-Shen Yen (2013) studied about the significance of "Social Influence" and utilitarian value for usage intention. They indicated that "Social Influence" is absolutely related with utilitarian value, social value, and hedonic value. They also found intermediating outcome of social value between "Social Influence" and usage intention in SNS, but utilitarian value does not have similar effect. Akhtar, Thyagaraj and Das, (2018) have also suggested positive controlling effect of societal influence in a connection between extraversion and perceived investment performance. Contrary to this, it mediates negatively, the association between agreeability-perceived investment performance.

\subsection{Association Between "Social Influence" and Belief}

Mavrodiev, Tessone, and Schweitzer (2013) in their research have talked about the prominence of sentiments, belief in one's own estimation, "Beliefs" about the ability of others, and propensity to follow to the group opinion for usage of technology based banking transactions, under "Social Influence". Individual opinions are his or her subjective matter. In real life, views are highly codependent and influenced straight or circuitously by cultural norms, mass media and connections in social networks. The joint effects of these effects is known as "Social Influence". In other words, "Social Influence" means individuals acting in accordance to the "Beliefs" and expectations of others. "Social Influence" can be direct or indirect. The straight "Social Influence" is the consequence of one individual straight affecting the opinion of 
another whereas indirect influence is subtle psychological process and takes place when one's view and behaviour is influenced by the availability of information about others actions. Sociological influences are restricted to wisdom from others' schedules and mental and emotive factors are conferred small role at all. So, herding behaviour in finance has important study aspect naming "Social Influence" apart from sociological and psychological factors.

As "Social Influence" is the procedure by which persons adjust their view, review their "Beliefs", or modify their conduct as outcome of social interactions with other people (Moussaïd et al. (2013), with growth of technology, human beings are now exposed to variety of opinions, advice and information. Such information from social group is adjusted as per own "Beliefs".

The hypotheses which can be set from above review of literature is:

Ha 1: There is a positive association between "Beliefs" and individual Financial Behavior for Digital Banking

Ha 2: There is a positive association between "Values" and individual Financial Behavior for Digital Banking

Ha 3: There is a positive association between "Social Influence" and individual Financial Behavior for Digital Banking

Ha 4: There is a positive association between "Social Influence" and belief.

Ha 5: There is a positive association between "Social Influence" and "Values".

Ha 6: There is a positive association between "Social Influence" and belief taken together with individual Financial Behavior for Digital Banking

Ha 7: There is a positive association between "Values" \& "Social Influence" taken together with individual Financial Behavior for Digital Banking

Ha 8: There is a positive association between belief, "Values" \& "Social Influence" taken together with individual Financial Behavior for Digital Banking

Ha 9: There is a positive he mediation effect of "Values" for association between "Social Influence" on individual Financial Behavior for Digital Banking

Ha 10: Ha 9: There is a positive mediation effect of belief for association between "Social Influence" and individual Financial Behavior for Digital Banking

\section{Objectives}

- To plan, develop and do standardization of a measure for "Social Influence", individual Financial Behavior, "Values" \& Belief for Digital Banking.

- To discover underlying factors for "Social Influence", individual Financial Behavior, "Values" \& Belief for Digital Banking. 


\section{Macrothink}

International Journal of Accounting and Financial Reporting

ISSN 2162-3082

2019, Vol. 9, No. 4

- To discover the causal association between "Beliefs" and individual Financial Behavior for Digital Banking.

- To discover the causal association between "Values" and individual Financial Behavior for Digital Banking.

- To discover the causal association between "Social Influence" and individual Financial Behavior for Digital Banking.

- To discover the causal association between "Social Influence" and "Values".

- To discover the causal association between "Social Influence" and belief.

- To discover the causal association between "Social Influence" and belief taken together on individual Financial Behavior for Digital Banking

- To discover the causal association between "Values" \& "Social Influence" taken together on individual Financial Behavior for Digital Banking

- To discover the causal association between belief, "Values" \& "Social Influence" taken together on individual Financial Behavior for Digital Banking

- To discover the mediation effect of "Values" for association between "Social Influence" and individual Financial Behavior for Digital Banking

- To discover the mediation effect of belief for association between "Social Influence" and individual Financial Behavior for Digital Banking

\section{Research Methodology}

The present work is a quantitative work and done on the sample of investors residing in the Madhya Pradesh region of India. After establishing reliability of the instruments through a pilot survey of 50 respondents, the data was collected from 350 individual's investors who were using digital banking.

For the purpose of data collection, questionnaires for "Social Influence", individual Financial Behavior for Digital Banking, "Values" \& Belief were designed and used. In total 500 questionnaires were sent for collecting data. Out of which 380 questionnaires were received. Further, out of those 380 questionnaires, only 350 questionnaires were found usable. Appropriate statistical tools were used to analyze the data received.

Reliability was checked through Cronbach's Alpha; Exploratory Factor analysis knowing the factors of variables "Social Influence", Individual Financial Behavior for Digital Banking, "Values" \& Belief. Also Regression analysis for establishing causal association between different variables of the work taken either individually or together. Sobel's measure was considered for computing the mediation effect of "Values" for association between "Social Influence" and Individual Financial Behavior for Digital Banking as well as for belief for association between "Social Influence" and Individual Financial Behavior for Digital Banking. 


\section{Reliability}

Table 1. Reliability figures

\begin{tabular}{lll}
\hline Name of Variables & Cronbach's Alpha' & No. of Items \\
\hline "Beliefs" & .788 & 10 \\
\hline "Values" & .921 & 10 \\
\hline "Social Influence" & .856 & 10 \\
\hline Individual Financial Behavior for Digital Banking & .854 & 10 \\
\hline
\end{tabular}

The Table 1 indicated the value of reliability index figures for "Beliefs", "Values", "Social Influence" and Individual Financial Behavior for Digital Banking was found 0.788, $0.921,0.856$ and 0.854 respectively (Utilising SPSS Software) in this work and the figures are far better value from the standard value which 0.70 (Normally,1978).

\section{Exploratory Factor Analysis}

EFA techniques were used to explore factors of the variables naming "Beliefs", "Values", "Social Influence" and Individual Financial Behavior for Digital Banking. "Kaiser meyer olkin measure of sampling adequately" indicated KMO value greater than .7 for all the variables demonstrating that the sample size was good enough to treat the sampling data as normally distributed. The result of "Bartlett test of chi square" with given degree of freedom is .000 . This means that the response matrix for all the variable is not an identity matrix.

Table 2. Exploratory factor analysis

\begin{tabular}{lllll} 
Variable & $\begin{array}{l}\text { Kaiser-Meyer-Olkin } \\
\text { Measure } \\
\text { Sampling } \\
\text { Adequacy' }\end{array}$ & $\begin{array}{l}\text { of } \\
\text { Bd Sphericity } \\
\text { Approx. } \\
\text { Chi-Square' }\end{array}$ & $\begin{array}{l}\text { of Sphericity } \\
\text { Df }\end{array}$ & $\begin{array}{l}\text { Sig' } \\
\text { of Sphericity }\end{array}$ \\
\hline Belief & .760 & 1046.844 & 45 & .000 \\
\hline $\begin{array}{l}\text { Individual } \\
\text { Financial } \\
\text { Behavior } \\
\text { Digital } \\
\text { Banking } \\
\text { Digital } \\
\text { Banking }\end{array}$ & .859 & 1258.981 & 45 & .000 \\
\hline & & & & \\
\hline
\end{tabular}


"Social

.816

1044.903

45

.000

Influence"

"Values" $\quad .760$

1046.844

45

.000

\subsection{Exploring the Factors of "Beliefs"}

EFA test was applied for exploring the factors of Variable Naming Belief. It resulted into three factors. The details of items converged and variance explained is given below in the table.

\subsection{Factor Description "Beliefs"}

It is critical that the respondents are closely involved in the process of developing, formalizing and agreeing the final set of approved "Beliefs". It takes time to develop confidence that the financial "Beliefs" will enable them to deliver better financial performance to align with these "Beliefs".

Importance of finance (FB1): This element has a total variance 29.954.

Credit worthiness (FB2): This element has total variance 12.885.

Tracking of Income \& Expenditure (FB3): This element has total variance 6.000.

\subsection{Factor Description: Individual Financial Behavior for Digital Banking}

The factors responsible for Individual "financial behaviour" for Digital Banking came out to be:

Investment and Information (IFB1): This element has total variance 38.915.

Frequent Usage of Digital Banking Platforms (IFB2): This element has a total variance 7.426.

\subsection{Factor Description "Social Influence"}

"Social Influence" is the transformation in behavior that one person causes in another, purposefully or by mistake, because of the manner in which the changed person sees themselves in association to the influencer, other people and society.

Cooperation in Society (FSI1): This element has total variance 33.975.

Value in Society (FSI2): This element has a total variance 6.210.

Image (FSI3): This element has a total variance 5.203.

\subsection{Factor Description "Values”}

"Values" are considered as something which is held to deserve; the status, substance, or worth of something.

Financial needs (FV1): This element has total variance 29.954.

Income and Obligation (FV2): This element has total variance 12.885. 


\section{Macrothink}

International Journal of Accounting and Financial Reporting

ISSN 2162-3082 2019, Vol. 9, No. 4

Health Concern (FV3): This element has total variance 6.000.

\section{Linear Regression}

Simple Linear Regression' was applied to understand the causativeness between "financial behaviour" and belief, Financial belief \& value, "financial behaviour"\& "Social Influence", "Values" \& "Beliefs" and Belief \& "Social Influence". Further multiple regression was used to establish causal association with Financial behavior and "Beliefs", "Values" \& "Social Influence"; Financial behavior and "Beliefs" \& "Social Influence"; Individual Financial behavior for Digital Banking and "Values" \& "Social Influence"

The results of the same are discussed below in Tables.

\begin{tabular}{|c|c|c|c|c|c|c|c|c|}
\hline $\begin{array}{l}\text { Dependent } \\
\text { Variable }\end{array}$ & $\begin{array}{l}\text { Independent } \\
\text { Variable }\end{array}$ & $\begin{array}{l}\boldsymbol{R} \\
\text { square } \\
\text { Value }\end{array}$ & $\begin{array}{l}F \text { value and } \\
\text { Sig }\end{array}$ & $\begin{array}{l}\text { Unstandardized } \\
\text { Coefficient } \\
\text { Beta }\end{array}$ & $\begin{array}{l}\text { Standardized } \\
\text { Coefficients }\end{array}$ & $\begin{array}{l}T \text { value and } \\
\text { Significance }\end{array}$ & & \\
\hline $\begin{array}{l}\text { Individual } \\
\text { Financial } \\
\text { behavior for } \\
\text { Digital Banking }\end{array}$ & Belief & .593 & $\begin{array}{l}508.019 \\
@ .000\end{array}$ & .821 & .770 & 22.539@.000 & & \\
\hline $\begin{array}{l}\text { Individual } \\
\text { Financial } \\
\text { behavior for } \\
\text { Digital Banking }\end{array}$ & Value & .114 & 44.840@.000 & .339 & .338 & 6.696@.000 & & \\
\hline $\begin{array}{l}\text { Individual } \\
\text { Financial } \\
\text { behavior for } \\
\text { Digital Banking }\end{array}$ & $\begin{array}{l}\text { "Social } \\
\text { Influence" }\end{array}$ & .372 & 206.287@.000 & .633 & .610 & $14.363 @ .000$ & & \\
\hline "Values" & $\begin{array}{l}\text { "Social } \\
\text { Influence" }\end{array}$ & .144 & $58.607 @ .000$ & .393 & .380 & 7.656@.000 & & \\
\hline Belief & $\begin{array}{l}\text { "Social } \\
\text { Influence" }\end{array}$ & .340 & 179.578@.000 & .568 & .583 & 13.401@.000 & & \\
\hline $\begin{array}{l}\text { Dependent } \\
\text { Variable }\end{array}$ & $\begin{array}{l}\text { Independent } \\
\text { Variable }\end{array}$ & $\begin{array}{l}\text { Adjusted } \\
R \\
\text { square } \\
\text { Value }\end{array}$ & $\begin{array}{l}F \text { value and } \\
\text { Sig }\end{array}$ & $\begin{array}{l}\text { Unstandardized } \\
\text { Coefficient } \\
\text { Beta }\end{array}$ & & $\begin{array}{l}\text { Standardized } \\
\text { Coefficients }\end{array}$ & T value & Significance \\
\hline $\begin{array}{l}\text { Individual } \\
\text { Financial }\end{array}$ & $\begin{array}{l}\text { "Beliefs", } \\
\text { "Values" }\end{array}$ & .639 & 207.091@.000 & $\begin{array}{l}\text { Belief total } \\
\text { "Values" total }\end{array}$ & $\begin{array}{l}.665 \\
.107\end{array}$ & $\begin{array}{l}.624 \\
.107\end{array}$ & $\begin{array}{l}15.765 \\
3.067\end{array}$ & $\begin{array}{l}.000 \\
.002\end{array}$ \\
\hline $\begin{array}{l}\text { Behavior for } \\
\text { Digital Banking }\end{array}$ & $\begin{array}{l}\text { and "Social } \\
\text { Influence" }\end{array}$ & & & $\begin{array}{l}\text { "Social } \\
\text { Influence" }\end{array}$ & .213 & .205 & 4.945 & .000 \\
\hline $\begin{array}{l}\text { Individual } \\
\text { Financial }\end{array}$ & $\begin{array}{l}\text { "Beliefs" } \\
\text { and "Social }\end{array}$ & .630 & 298.700@.000 & Belief total & .252 & .243 & 6.077 & .000 \\
\hline $\begin{array}{l}\text { Behavior for } \\
\text { Digital Banking }\end{array}$ & Influence" & & & $\begin{array}{l}\text { "Social } \\
\text { Influence" }\end{array}$ & .670 & .628 & 15.682 & .000 \\
\hline $\begin{array}{l}\text { Individual } \\
\text { Financial }\end{array}$ & $\begin{array}{l}\text { "Values" } \\
\text { and "Social }\end{array}$ & .382 & 108.777@.000 & value & .124 & .124 & 2.729 & .007 \\
\hline $\begin{array}{l}\text { Behavior for } \\
\text { Digital Banking }\end{array}$ & Influence" & & & $\begin{array}{l}\text { "Social } \\
\text { Influence" }\end{array}$ & .584 & .563 & 12.374 & .000 \\
\hline
\end{tabular}

\subsection{Individual Financial Behavior for Digital Banking as Dependent Variables and Belief as} Independent Variable

The model summary table indicated the value of $\mathrm{R}$ square which was found to be 0.593 indicating that financial "Beliefs" explained 59\% variance on Individual Financial Behavior for Digital Banking. The current Model indicated financial "Beliefs" and Individual Financial Behavior for Digital Banking have a good fit checked through F-test value from table which was 508 at 0.000 level of significance. The result of F-test clearly indicated that current model is highly fit. Coefficient table indicated that coefficient of financial "Beliefs" is .821. It means that one unit change in independent variable would lead to .821 units change in dependent variable. Further it was found that the $\beta$ value is 0.770 verified through $t$ test value 22.539 
significant at 0.000 .

8.2 Individual Financial Behavior for Digital Banking as Dependent Variables and "Values" as Independent Variable

The model summary table indicated the value of $\mathrm{R}$ square to be 0.114 demonstrating that financial "Values" explained 11.4 variance on Individual Financial Behavior for Digital Banking. The current Model has a good fit checked through F-test value of 44.840 significant at $0 \%$. Coefficient table indicated that coefficient of financial "Values" is .339. It means that one unit change in independent variable would lead to .339 units change in dependent variables. Further it was found that the value of Beta 0.338 verified through t test value 6.696 significant at 0.000 level of significance.

\subsection{Individual Financial Behavior for Digital Banking as Dependent Variables and "Social Influence" as Independent Variable}

The model summary table indicated the R square to be 0.372 indicating that "Social Influence" explained 37.2 variance on Individual Financial Behavior for Digital Banking. The current Model has a good fit checked through F-test value from table which was 206.287 significant at $0 \%$. The result of F-test clearly indicated that current model is highly fit.

Coefficient table indicated that coefficient of financial "Values" is .633. It means that one unit change in independent variable would lead to .633 units change in dependent variables. Further it was found that the value of Beta 0.610 verified through t test value 614.363 noteworthy at 0.000 level of significance.

\section{4 "Values" as Dependent Variables and "Social Influence" as Independent Variable}

The model summary table indicated the value of $\mathrm{R}$ square which was found to be 0.380 indicating that "Social Influence" explains 38\% variance on Individual Financial Behavior for Digital Banking. The current Model has a good fit which can be seen through F-test value from table which was 58.607 significant at $0 \%$. Coefficient table indicated that coefficient of financial "Values" is .393. It means that one unit change in independent variable would lead to .393 units change in dependent variables. Further it was found that the value of Beta 0.380 tested through $t$ test value 7.656 significant at 0.000 level of significance.

\subsection{Belief as Dependent Variables and "Social Influence" as Independent Variable}

The model summary table indicated $\mathrm{R}$ square as 0.340 indicating that "Social Influence" explained 34\% variance on "Social Influence". The current Model indicated "Social Influence" and belief have a good fit checked through F-test value from table which was 179.578 significant at 0.000 level of significance. The end result of F-test clearly indicated that current model is highly fit. Coefficient table indicated that coefficient of financial "Values" is .568. It means that one unit change in independent variable would lead to .568 units change in dependent variables. Further it was found that the value of Beta 0.583 verified through $t$ test value 13.401 significant at 0.000 level of significance. 


\section{Multiple Regressions}

9.1 Individual Financial Behavior for Digital Banking as Dependent Variables and "Beliefs", "Values" and "Social Influence" as Independent Variable

The model summary table indicated the value of $\mathrm{R}$ square which was found to be 0.642 indicating that $f$ "Beliefs". "Values" and "Social Influence" as independent variable and Individual Financial Behavior for Digital Banking as dependent variables explained $64.25 \%$ variance on Individual Financial Behavior for Digital Banking. The current Model indicated "Beliefs", "Values" and "Social Influence" has good fit with Individual Financial Behavior for Digital Banking as checked through F-test value from table which was 207.091. significant at $0 \%$. The result of F-test clearly indicated that current model is highly fit. Coefficient table indicated that coefficient of "Beliefs" is .821, "Values" is .107, "Social Influence" is .213. It means that one unit change in independent variable would lead to .821,.107and .213 respectively units change in dependent variable. Further it was found that the $\beta$ value of belief, "Values" and "Social Influence" is $0.624,0.107$ and .205 respectively tested through t test value of belief, "Values" and "Social Influence" is 15.765, 3.067 and 4.945 respectively, significance of belief, "Values" and "Social Influence" at 0.000, .002 and .000 level of significance.

9.2 Individual Financial Behavior for Digital Banking as Dependent Variables and "Beliefs" and "Social Influence" as Independent Variable

The model summary table indicated the value of $\mathrm{R}$ square value of 0.633 indicating that "Beliefs" and "Social Influence" explains 63.3\% variance on Individual Financial Behavior for Digital Banking. The current Model has a good fit with F-test value of 298.700 significant at $0 \%$.

Coefficient table indicated that coefficient of "Beliefs" is .252 and "Social Influence" is .670. It means that one unit change in independent variable would lead to .252 and .670 respectively units change in dependent variable. Further it was found that the $\beta$ value of belief and "Social Influence" is 0.243 and .628 respectively tested through t test value of belief and "Social Influence" is 6.077 and 15.682 respectively, significance of belief and "Social Influence" at 0.000 and .000 level of significance.

9.3 Individual Financial Behavior for Digital Banking as Dependent Variables and "Values" and "Social Influence" as Independent Variable

The R square value of 0.385 indicates that "Values" and "Social Influence" explained $38.5 \%$ variance on Individual Financial Behavior for Digital Banking. The model F-test value from table was 108.777 significant at $0 \%$. The result of F-test clearly indicated that current model is highly fit.

Coefficient table indicated that coefficient of "Values" is .124 and "Social Influence" is .584. It means that one unit change in independent variable would lead to .124 and .584 respectively units change in dependent variable. Further it was found that the $\beta$ value of "Values" and "Social Influence" is .124 and .563 respectively tested through t test value of "Values" and "Social Influence" is 2.729 and 12.374 respectively, significance of "Values" and "Social 


\section{Macrothink \\ International Journal of Accounting and Financial Reporting \\ ISSN 2162-3082 2019, Vol. 9, No. 4}

Influence" at 0.007 and .000 level of significance.

\section{Mediation Effect}

10.1 Mediation Effect Between "Social Influence", "Values" and Individual Financial Behavior for Digital Banking With "Values" as Mediator

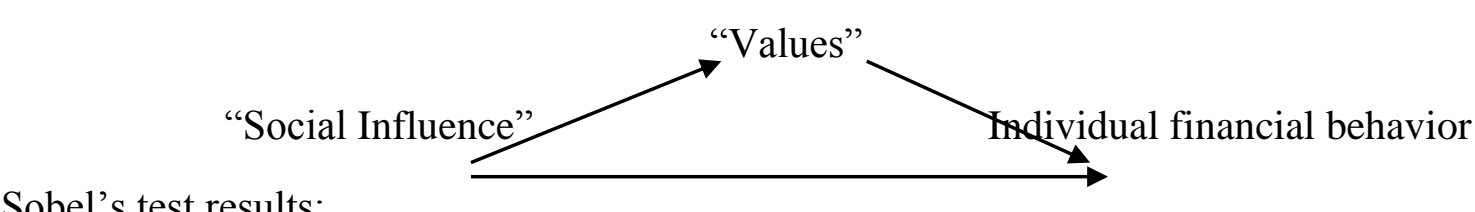

Sobel's test results:

\begin{tabular}{ll}
\hline Test statistic & 5.03323791 \\
\hline S.E & .02646944 \\
\hline P value & $4.8 \mathrm{e}-7$ \\
\hline
\end{tabular}

10.2 Mediation Effect Between "Social Influence”, Belief and Individual Financial Behavior for Digital Banking With Belief as Mediator

Sobel's test results:

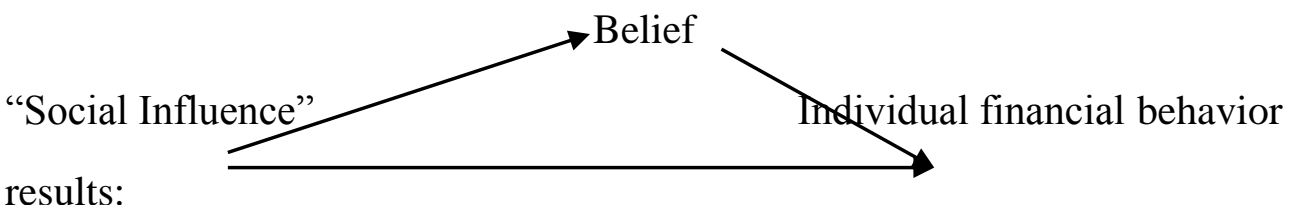

\begin{tabular}{ll}
\hline Test statistic & 11.63231409 \\
\hline S.E & .04008901 \\
\hline P value & 0 \\
\hline
\end{tabular}

This null hypothesis is rejected. It means that mediation effect of belief is not equal to zero.

\section{Discussion}

The results of the research show a significant association between the "Social Influence" and individual "financial behaviour" for digital banking and there is mediation effect of "Values" and "Beliefs" in this relationship. Results showed that "Values" and "Beliefs" an individual brings can temperate the strength of the association between the dimensions of individual "Social Influence" and the "financial behaviour".

In support of the results is the work of Rob Gray who put forward that social environment, culture etc influence the "Values" norms and behaviors, including the financial behavior of individual. As we understand Financial "Beliefs" have significant association with Individual Financial Behavior. "Beliefs" have direct effect on the psychology of an individual which in turn effects the conduct of an individual further. "Beliefs" also add to the "Values" of an 
individual. "Values" of an individual effects the individual financial behavior and even more for digital banking which help an individual to achieve the finance of a home including budgeting, saving, investing debt management and other aspects related to personal money where by an individual can lead to good lifestyle (Byely et al., 2000). "Social Influence" plays a very important role in Individual Financial Behavior in context of Digital Banking. "Social Influence" refers to peer influence and parent socialization. "Social Influence" involves the exercise of social power by a person or group to change the attitude or behavior of other persons in particular direction. Besides parenting factors, peer influence also predicts individual's financial behavior. Individuals interact with others in their particular social environment directly or indirectly influence their financial behavior.

\section{Conclusion and Implications of the Study}

The study was done with the objectives of discovering underlying factors for "Social Influence", individual Financial Behavior for Digital Banking, "Values" \& Belief as well as to discover the causal association between belief, "Values" \& "Social Influence" taken individually as well as taken together on individual Financial Behavior for Digital Banking. Further the mediation effect of "Values" for association between "Social Influence" and individual Financial Behavior for Digital Banking along with the mediation effect of belief for association between "Social Influence" and individual Financial Behavior for Digital Banking was also checked.

The results indicate finding out factors responsible for belief formation (Importance of finance, Credit worthiness, Tracking of Income \& Expenditure), "financial behaviour" for digital banking (Investment and Information; Frequent Usage of Digital Banking Platforms); "Social Influence" (Cooperation in Society; Value in Society and Image) and "Values" (Financial needs, Income and Obligation and Health Concern).

It has been concluded that the Individual Financial Behavior for Digital Banking is dependent upon the "Values", "Beliefs" and "Social Influence". Also there is presence of mediation effect of "values" and beliefs for digital banking.

The development of global economy has brought a serious change into the financial system which is visible from use of technology in banking. Individuals now can do many transactions quickly by use of different digital banking platforms like internet banking, mobile banking and many more. The study indicates that individuals now looks for finance as an important part of their life. They believe that tracking of income and expenditure as well as credit worthiness is important. In this technical era, they look for different investment and other related information available on digital banking platform and then they increase the frequency of usage. For the usage they see what are the trends in the society regarding usage of digital banking platforms, is the individual value matches with the value norms of the society (in which individual lives) for usage, will there be cooperation provided to him for making usage at ease. Also individual checks that his needs, income, obligations etc. doesn't get affected negatively with the use of the digital banking. Individual also assess whether digital transformation is making his/her task at ease. So understanding the role of "Social Influence", "Values" and belief regarding digital platforms, strategies can be formed by the financial institutions so that targeting on "Values" 
and "Beliefs", non-users of digital banking platforms can be converted into users of digital banking platforms. Sometime the actual worth of something is understood only after experiencing it. Incentive and simulated trials can be given to the non-uses to make them attract towards digital banking platforms.

\section{References}

Ajzen, I. (1991). The theory of planned behavior. Organizational Behavior and Human. Decision Processes, 50, 179-211. https://doi.org/10.1016/0749-5978(91)90020-T

Ajzen, I. (2005). Attitudes, Personality, and Behaviour (2nd ed.). Maidenhead, UK: Open University Press.

Ajzen, I., \& Fishbein, D. (2009). Predicting and changing behavior. The reasoned action approach. Retrieved from books.google.com

Akhtar, F., Thyagaraj, K., \& Das, N. (2018). The impact of "Social Influence" on the relationship between personality traits and perceived investment performance of individual investors. International Journal of Managerial Finance, 14(1), 130-148. https://doi.org/10.1108/IJMF-05-2016-0102

Alsajjan, B., \& Dennis, C. (2010). Internet Banking Acceptance Model. Cross-Market Examination. Journal of Business Research, 63(9-10), 957-963. https://doi.org/10.1016/j.jbusres.2008.12.014

Borden, L. M., Lee, S. A., Serido, J., \& Collins, D. (2008). Changing College Students' Financial Knowledge, Attitudes, and Behavior Through Seminar Participation. Journal of Family and Economic Issues, 29(1), 23-40. https://doi.org/10.1007/s10834-007-9087-2

Byely, L., Archibald, A. B., Graber, J. A., \& Brooks-Gunn, J. (2000). A Prospective Study of Familial and "Social Influence" on Girls' Body Image and Dieting. International Journal of Eating Disorders, 28(2), 155-64. https://doi.org/10.1002/1098-108X(200009)28:2<155::AID-EAT4>3.0.CO;2-K

Cokely, E., \& Kelley, C. (2009). Cognitive abilities and superior decision making under risk: A protocol analysis and process model evaluation. Judgment and Decision Making, 4(1), 20-33.

Cude, B., Lawrence, F., Lyons, A., Metzger, K., LeJeune, E., Marks, L., \& Machtmes, K. (2006). College students and financial literacy: What they know and what we need to learn. Proceedings of the Eastern Family Economics and Resource Management Association (pp. 102-109).

Dilek, D., Özgür, B., Rutkay, A., \& Ceren, D. T. (2019). Relationship Between Financial Literacy and Financial Self- Efficacy: A Research On University Students. Conference: ICOAEF'18.

Furnham, A. (1996). Attitudinal correlates and demographic predictors of monetary "Beliefs" and behaviours. Journal of Organizational Behavior, 17(4), 375-388. https://doi.org/10.1002/(SICI)1099-1379(199607)17:4<375::AID-JOB767>3.0.CO;2-8 
Gigerenzer, G. \& Gaissmaier, W. (2011). Heuristic Decision Making. Annual Review of Psychology, 62, 451-482. https://doi.org/10.1146/annurev-psych-120709-145346

Grube, J. W., Daniel M. M, \& Sandra J. B. (1994). Inducing Change in "Values", Attitudes, and Behaviors: Belief System Theory and the Method of Value Self-Confrontation. Journal of Social Issues, 50, 153-174. https://doi.org/10.1111/j.1540-4560.1994.tb01202.x

Hsu, C. L., Lu, H. P., \& Hsu, H. H. (2007). Adoption of the mobile Internet. An Empirical Study of Multimedia Message Service. Omega, 35(6), 715-726. https://doi.org/10.1016/j.omega.2006.03.005

Jamal, A. A. A., Ramlan, W. K., Karim, M. R. A., Mohidin, R., \& Osman, Z. (2015). The Effects of "Social Influence" and Financial Literacy on Savings Behavior: A Study on Students of Higher Learning Institutions in Kota Kinabalu, Sabah. International Journal of Business and Social Science, 6, 110-119.

Jamal, M. E. A., Madya, S. B. M. S., \& Sany, S. B. M. M. (2018). The Effect of Family, Peer, Behavior, Saving and Spending Behavior on Financial Literacy among Young Generations. International Journal of Organizational Leadership, 7, 309-323. https://doi.org/10.33844/ijol.2018.60258

Kahneman, D. (2003). Maps of bounded rationality: Psychology for behavioral economics. $\begin{array}{llll}\text { The American Economic Review, 1449-1475. } & \text { 93, }\end{array}$ https://doi.org/10.1257/000282803322655392

Kirkcaldy, B., \& Furnham, A. (1993). Predictors of "Beliefs" About Money. Psychological Reports, 73(3), 1079-1082. https://doi.org/10.2466/pr0.1993.73.3f.1079

Klontz, B., Britt, S. L., Mentzer, J., \& Klontz, T. (2011). Money "Beliefs" and financial behaviors: Development of the Klontz Money Script Inventory. Journal of Financial Therapy, 2(1), 1. https://doi.org/10.4148/jft.v2i1.451

Kluckhohn, C. (1951). "Values" and Value-Orientations in the Theory of Action: An Exploration in Definition and Classification. In T. Parsons, \& E. Shils (Eds.), Toward a General Theory of Action (pp. 388-433). Harvard University Press, Cambridge. http://doi.org/10.4159/harvard.9780674863507.c8

Lamb, C. W., Hair, J. F., \& McDaniel, C. (2011). MKTD Student Edition. South Western, Mason.

Logasvathi, M. (2016). The Level of Understanding and Strategies to Enhance Financial Literacy Among Malaysian. Economic and Financial Issues, 6(3S), 130-139.

Lusardi, A., \& Mitchell, O. (2007). Financial literacy and retirement planning: New evidence from the Rand American Life Panel. Michigan Retirement Research Center Working Paper 2007-157. https://doi.org/10.2139/ssrn.1095869

Mavrodiev, P., Tessone, C. J., \& Schweitzer, F. (2018). Quantifying the effects of "Social Influence". Scientific Reports. 


\section{$\triangle 1$ Macrothink}

International Journal of Accounting and Financial Reporting

ISSN 2162-3082

2019, Vol. 9, No. 4

Moussaïd, M., Kämmer, J. E., Analytis, P. P., \& Neth, H. (2013). "Social Influence” and the Collective Dynamics of Opinion Formation. PLoS ONE 8(11), e78433. https://doi.org/10.1371/journal.pone.0078433

Mustikasari. (2007). Empirical Research on the Agency Taxpayer Compliance in Manufacturing Industry Company in Surabaya. National Symposium on Accounting. Retrieved from http://www.lintasberita.web.id/Akuntansi/Kumpulan

Nayeem, T. (2012). Cultural Influences on Consumer Behaviour. International Journal of Business and Management, 7(21), 78-91. https://doi.org/10.5539/ijbm.v7n21p78

Newman, R. S. (2000). Development of Children's Adaptive Help Seeking: The Role of Parents, Teachers, and Peers. Developmental Review, 20, 350-404. https://doi.org/10.1006/drev.1999.0502

Norvilitis, J. M., \& MacLean, M. G. (2010). The Role of Parents in College Students' Financial Behaviors and Attitudes. Journal of Economic Psychology, 31(1), 55-63. https://doi.org/10.1016/j.joep.2009.10.003

Odek, F. (2013). Financial literacy and individual "financial behaviour". MIS Quarterly, 13(3), 319-340.

Postmus, J. L. (2011). Understanding Financial Literacy with Survivors of Intimate Partner $\begin{array}{lllll}\text { Violence. } & \text { Issue } & \text { Brief. } & \text { Retrieved }\end{array}$ http://www.cfs.wisc.edu/briefs/Postmus2011_ResearchBrief. Pdf

Primmer, J. (2018). Belief. In J. Primmer (Eds.), the Stanford Encyclopedia of Philosophy. Stanford. CA: The Metaphysics Research Lab.

Robb, C. A., Babiarz, P., \& Woodyard, A. (2012). The Demand for Financial Professionals' Advice: The Role of Financial Knowledge, Satisfaction, and Confidence. Financial Services Review, 21, 291-305.

Sam, Y. T., Geetha, C., \& Mohidin, R. (2012). What Were the Factors that Influence the Financial Management Behavior of Undergraduates?. International Journal of Business Trends and Technology, 2(1).

Shim, S., Barber, B. L., Card, N. A., Xiao, J. J., \& Serido, J. (2010). Financial socialization of first-year college students: The roles of parents, work, and education. Journal of Youth and Adolescence, 39(12), 1457-1470. https://doi.org/10.1007/s10964-009-9432-x

Smith, P. B., \& Bond, M. H. (1998). Social psychology across cultures (2nd ed.). Hemel Hempstead: Harvester/Wheatsheaf.

Triplett, N. (1898). The Dynamogenic Factors in Pacemaking and Competition. American Journal of Psychology, 9, 507-533. https://doi.org/10.2307/1412188

Wallen, K. (1996). Nature needs nurture: the interaction of hormonal and "Social Influence"s on the development of behavioral sex differences in rhesus monkeys. Journal Hormones and Behavior, 30(4), 364-378. https://doi.org/10.1006/hbeh.1996.0042 


\section{Macrothink}

International Journal of Accounting and Financial Reporting ISSN 2162-3082

Yen, Y. (2013). The relationship among "Social Influence", perceived value, and usage intention in social networking sites. 3rd International Conference on Consumer Electronics, Communications and Networks. https://doi.org/10.1109/CECNet.2013.6703427

\section{Copyright Disclaimer}

Copyright for this article is retained by the author(s), with first publication rights granted to the journal.

This is an open-access article distributed under the terms and conditions of the Creative Commons Attribution license (http://creativecommons.org/licenses/by/4.0/) 